\title{
GAMBARAN LEUKOSIT PADA SEDIMEN URINE IBU HAMIL
}

\author{
Hotmauli, Imelda Fitri*, Mega Pratiwi Irawan, Sheryn Fildzah Azhari \\ Fakultas Farmasi dan Ilmu Kesehatan, Universitas Abdurrab, Jl. Riau Ujung No.73 Pekanbaru, Riau \\ 28291, Indonesia \\ *imelda.fitri@univrab.ac.id (+6281371180017)
}

\begin{abstract}
ABSTRAK
Kejadian infeksi saluran kemih tertinggi pada kehamilan trimester III yaitu 36,9 \%. Leukosit urine merupakan salah satu pemeriksaan penunjang pada penyakit ginjal dan infeksi saluran kemih. Tujuan penelitian ini untuk mengetahui gambaran leukosit pada sedimen urine Ibu hamil di Kelurahan Babussalam Kota Duri. Penelitian ini menggunakan desain penelitian deskriptif dengan sampel penelitian ibu hamil yang memenuhi kriteria inklusi dan eksklusi berjumlah 27 responden. Gambaran leukosit urine dengan menggunakan metode mikroskopis urine dengan meggunakan mikroskop. Analisa data hasil pemeriksaan leukosit pada sedimen urine ibu hamil disajikan dalam bentuk deskriptif berupa gambar dan tabel. Hasil penelitian didapat kansebanyak 8 responden $(30 \%)$ memiliki jumlah leukosit $>5 /$ LPB dan 19 responden $(70 \%)$ memiliki jumlah leukosit 0-5/LPB. Dari 8 responden (30\%) yang leukosit urine >5/LPB yaitu 1 responden dari trimester I, 1 responden dari trimesrter II dan 6 responden dari Trimester III. Ibu hamil trimester III mengalami leukosit urine tidak normal terbanyak yang disebabkan oleh perubahan yang terjadi selama kehamilan, jumlah leukosit yang tidak normal dapat menyebabkan infeksi saluran kemih bahkan beresiko terjadinya persalinan prematur dan gangguan pertumbuhan janin.
\end{abstract}

Kata kunci: ibu hamil; infeksi saluran kemih; leukosit urine

\section{DESCRIPTION OF LEUKOCYTES IN URINE SEDIMENTS OF PREGNANT WOMEN}

\begin{abstract}
The highest incidence of urinary tract infections in the third trimester of pregnancy is 36,9\%. Urine leukocytes are one of the supporting test for kidney disease and urinary tract infections. The purpose of this study was to determine of leucocytes in the urine sediment of pregnant woment In Babusalam, Duri City. This research used descriptive research design with 27 samples of pregnant women with method urine microscopic. Analysis of data on the results of examination of leukocytes in the urine sediment of pregnant women is presented figures and tables. The results showed that 8 respondents (30\%) had leukocytes $>5 / L P B$ and 19 respondents (70\%) had leukocytes of 0-5/LPB. Of 8 respondents (30\%) whose urine leukocytes $>5 / L P B$ that is 1 respondent from trimester I, 1 respondent from trimester II and 6 respondents from trimester III. Pregnant mother on trimester III have the most abnormal urine leukocytes caused by change that occur during increasing gestational age. Abnormal leucocyte counts can cause urinary tract infections and even risk of preterm labor and fetal growth disorders.
\end{abstract}

Keywords: pregnant mother; urine leukocyte; urinary tract infection

\section{PENDAHULUAN}

Kehamilan merupakan fertilisasi atau penyatuan spermatozoa dan ovum yang dilanjutkan dengan inplantasi atau nidasi. Kehamilan normal bila dihitung mulai masa fertilisasi hingga lahirnya bayi berlangsung selama 9 bulan kalender internasional atau 40 minggu. 
Kehamilan dibagi menjadi 3 trimester yaitu trimester I mulai usia kehamilan 0-12 minggu, trimester II mulai usia kehamilan 13-27 minggu dan trimester III mulai usia kehamilan 28-40 minggu (Prawirohardjo S, 2011).

Pada masa kehamilan terjadi perubahan sistem perkemihan pada ginjal dan ureter. Perubahan pada ginjal ini diakibatkan oleh hormon estrogen dan progesteron, penekanan yang timbul akibat pembesaran usus dan peningkatan volume darah. Pada masa akhir kehamilan terjadi penekanan kandung kemih akibat turunnya kepala janin sehingga frekuensi buang air kecil menjadi meningkat (Prawirohardjo S, 2011).

Urine ibu hamil mengandung nutrisi lebih tinggi dari pada ibu yang tidak hamil. Nutrisi yang terkandung dapat berupa vitamin $\mathrm{B}$ dan vitamin $\mathrm{C}$ yang terlarut dalam air, asam amino dan glukosa yang dapat menjadi faktor penunjang pertumbuhan bakteri. Ambang ginjal yang rendah untuk mengekskresi glukosa dan asam amino serta penurunan fungsi pemekatan ginjal dapat menyebabkan sifat urine menjadi tidak terlalu asam selama kehamilan. Hal ini sangat baik untuk proliferasi mikroorganisme di ureter sehingga ditemukannya bakteri pada spesimen urine (bakteriuria) dan terjadinya infeksi bakteri (Infeksi Saluran Kemih) (Guyton, A. C., Hall, 2014). Infeksi bakteri atau Infeksi Saluran Kemih (ISK) dapat menyebabkan peningkatan jumlah leukosit dalam spesimen urine. Wanita cenderung memiliki jumlah leukosit urine yang lebih tinggi dari pada pria karena adanya kontaminasi vagina (Strasinger \& Lorenzo, 2014). Penentuan jumlah leukosit pada urine secara sederhana dapat dilakukan dengan cara deteksi keberadaan leukosit melalui pemeriksaan mikroskopis (Alvina, Wiradharma, D., Halim, L., Pusparini, Noor, S., dan Muliadi, 2013)

Bakteriuria asimtomatik meningkat sesuai umur kehamilan, dengan prevalensi tertinggi pada kehamilan trimester III yaitu 36,9\%. Hal ini dapat dipengaruhi oleh perubahan fisiologis, mekanis, dan hormonal selama kehamilan (Saimin J et al., 2018). Hasil leukosit urine tidak normal yaitu $29 \%$ yang diakibatkan oleh stress fisiologis yang diinduksi oleh kehamilan. Terdapat hubungan yang erat pada terjadinya persalinan prematur, preeklampsia, hipertensi, gangguan pertumbuhan janin dalam rahim/Intra Uterine Grow Restriction (IUGR) dan persalinan secara seksiosesar pada pasien hamil yang mengalami Infeksi Saluran Kemih (ISK) (Santoso APR; Laila M, 2019). Oleh karena itu infeksi saluran kemih pada kehamilan perlu mendapat perhatian yang serius. Penanganan yang cepat dapat membantu mencegah terjadinya komplikasi. Penelitian sebelumnya mengetahui gambaran leukosit pada ibu hamil dengan infeksi saluran kemih untuk dilakukan pengobatan lebih lanjut, namun pada penelitian ini merupakan upaya screening yang dilakukan dalam upaya preventif terhadap terjadinya infeksi saluran kemih yang berkontribusi kematian maternal dan neonatal. Tujuan khusus dari penelitian ini adalah untuk mengetahui gambaran leukosit pada sedimen urine Ibu hamil.

\section{METODE}

Penelitian ini menggunakan desain penelitian deskriptif. Pengambilan data dilakukan di Kelurahan Babusalam Kota Duri, sampel dibawa ke laboratorium RSUD Mandau Duri. Penelitian dilaksanakan setelah 
mendapat persetujuan dari RSUD Mandau dengan nomor 890/RSUDMDU/2020/302. Sampel penelitian adalah ibu hamil yang terdata di Kelurahan Babusalam Kota Duri yang memenuhi kriteria inklusi dan eksklusi. Kriteria inklusi yaitu ibu hamil yang bersedia jadi responden dengan usia produktif 18-55 tahun. Kriteria eksklusi yaitu ibu hamil yang terdiagnosa penyakit diabetes mellitus dan ibu hamil yang mengkonsumsi obat-obatan seperti golongan kortikosteroid. Sampel penelitian sebanyak 27 responden, dengan menggunakan teknik nonprobability sampling dengan metode purposive sampling.

Alat yang digunakan dalam penelitian ini adalah botol penampung urine, tabung reaksi, rak tabung reaksi, kaca objek, kaca penutup, pipet tetes, sentrifuge Nuve NV 800 dan mikroskop Olympus CX23. Bahan yang digunakan urin pagi ibu hamil yang disentrifuge untuk mendapatkan endapan urin sebagai bahan untuk pemeriksaan sedimen leukosit urin. Metode yang digunakan untuk pemeriksaan leukosit urin pada penelitian ini adalah metode mikroskopis urine dengan meggunakan alat mikroskop.

Prinsip pemeriksaan yaitu urin dipekatkan dengan menggunakan sentrifuge, kemudian supernatan dibuang. Pipet sedimen urine dan letakkan 1 sampai 2 tetes sedimen urine diatas kaca objek, lalu ditutup dengan kaca penutup ukuran 18x18 mm. Kemudian, amati di bawah mikroskop dengan lensa obyektif 10x (LPK) untuk mencari unsur silinder dan sel epitel dan lensa obyektif 40x (LPB) unsur-unsur lain (eritrosit, leukosit, bakteri, jamur dan unsur anorganik) (Ariffriana, D., Taher, E., dan Wahidah, 2016). Prosedur Penampungan Urine adalah botol penampung urin disediakan terlebih dahulu, pasien diminta untuk mencuci tangan sebelum penampungan sampel urine. Urine yang pertama keluar dibuang, lalu urine yang keluar selanjutnya ditampung dengan wadah steril yang telah disediakan. Urine diusahakan agar tidak membasahi bagian luar wadah (Arianda D, 2015). Prosedur Pemeriksaan Leukosit Urine adalah sampel urine dihomogenkan terlebih dahulu, kemudian masukkan 7 sampai $8 \mathrm{ml}$ ke dalam tabung sentrifuge dan putar selama 5 menit pada kecepatan 1500-2000 rpm. Tuang cairan atas keluar dari tabung dengan satu gerakan yang agak cepat kemudian tegakkan tabung sehingga cairan yang melekat pada dinding mengalir kembali ke dasar tabung. Kocok tabung untuk mensuspensikan sedimen. Pipet sedimen urin menggunakan pipet tetes sebanyak 1-2 tetes dan letakkan diatas kaca objek kemudian tutup dengan kaca penutup. Amati di bawah mikroskop dengan lensa obyektif 40x sebanyak 10 LPB. Leukosit urine masih dikatakan normal jika terdapat 0-5/LPB leukosit didalam urine (Gandasoebrata R, n.d.). Analisa data hasil pemeriksaan leukosit pada sedimen urine ibu hamil disajikan dalam bentuk deskriptif berupa gambar dan tabel.

\section{HASIL}

Karakteristik responden pada tabel 1 menunjukkan bahwa sebagian besar responden termasuk dalam kategori trimester III yaitu 10 responden (37\%) dan mayoritas responden berada dalam kehamilan pertama yaitu 14 responden (52\%). Lebih lanjut Tabel 2 hasil pemeriksaan leukosit urine pada sedimen urine ibu hamil menunjukkan bahwa 19 responden leukositnya 0 5/LPB yang berarti leukosit urine normal dan 8 responden luekositnya $\geq 5 /$ LPB berarti leukosit urine tidak 
normal. Hasil perbandingan gambar leukosit normal dan tidak normal pada ibu hamil dapat dilihat pada gambar 1 dan 2.

Tabel 1.

Karakteristik Responden ( $\mathrm{n}=27)$

\begin{tabular}{|c|c|c|}
\hline Variabel & $\mathrm{f}$ & $\%$ \\
\hline \multicolumn{3}{|l|}{ Usia Kehamilan } \\
\hline Trimester I & 8 & 30 \\
\hline Trimester II & 9 & 33 \\
\hline Trimester III & 10 & 37 \\
\hline \multicolumn{3}{|l|}{ Gravida } \\
\hline 1 & 14 & 52 \\
\hline 2 & 9 & 34 \\
\hline 3 & 2 & 7 \\
\hline 4 & 2 & 7 \\
\hline
\end{tabular}

Tabel 2.

Leukosit Pada Sedimen Urine Responden $(n=27)$

\begin{tabular}{cccc}
\hline $\begin{array}{c}\text { Pemeriksaan Leukosit Urine } \\
\text { Ibu Hamil }\end{array}$ & Frekuensi & Persentase (\%) & $\begin{array}{c}\text { Rentang Hasil } \\
\text { Leukosit } \\
\text { Urine/LPB }\end{array}$ \\
\hline 0-5/LPB & 19 & 70 & $0-5$ \\
$>5 /$ LPB & 8 & 30 & $7-45$ \\
Jumlah & 27 & 100 & \\
\hline
\end{tabular}

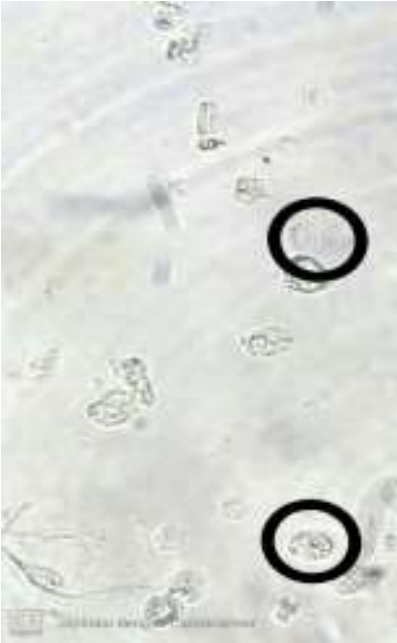

Gambar 1 : Leukosit Urine Normal

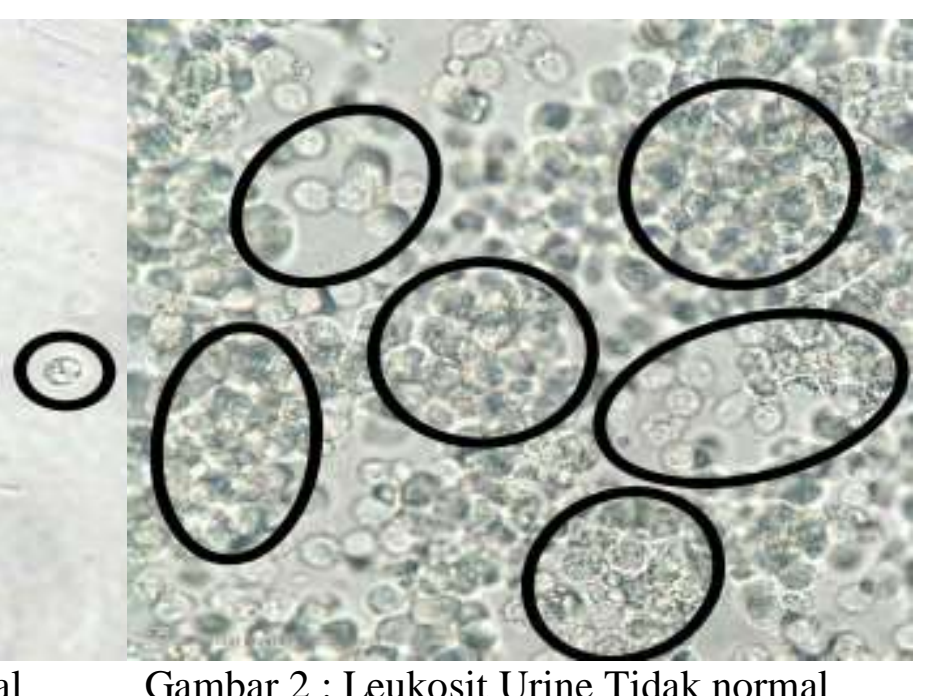

Gambar 2 : Leukosit Urine Tidak normal

Tabel 3.

Leukosit Urine Berdasarkan Usia Kehamilan ( $\mathrm{n}=27)$

\begin{tabular}{ccccc}
\hline Usia Kehamilan & $\mathrm{f}$ & $\%$ & Normal & Tidak Normal \\
\hline Trimester I & 8 & 30 & 7 & 1 \\
Trimester II & 9 & 33 & 8 & 1 \\
Trimester III & 10 & 37 & 4 & 6 \\
\hline
\end{tabular}


Tabel 4.

Leukosit Urine Berdasarkan Jumlah Kelahiran Anak (n=27)

\begin{tabular}{ccccc}
\hline Kelahiran Anak ke & $\mathrm{f}$ & $\%$ & Normal & Tidak Normal \\
\hline 1 & 14 & 52 & 12 & 2 \\
2 & 9 & 34 & 6 & 3 \\
3 & 2 & 7 & 1 & 1 \\
4 & 2 & 7 & 0 & 2 \\
\hline
\end{tabular}

Responden terbanyak adalah kelompok usia kehamilan trimester III yaitu sebanyak 10 responden (37\%), dan 6 responden leukosit urine tidak normal. Pada trimester I dan timester II masingmasing 1 responden leukosit urine tidak normal (Tabel 3).

Sebagian besar responden mengalami kehamilan anak pertama yaitu 14 responden $(52 \%)$ dan hanya 2 responden yang leukosit urine tidak normal. Responden mengalami kehamilan anak ke 2 yaitu sebanyak 9 responden $(34 \%)$ dengan kasus leukosit urin tidak normal terbanyak yaitu 3 responden (Tabel 4).

\section{PEMBAHASAN}

Hasil analisis menunjukkan bahwa mayoritas leukosit urin ibu hamil normal dan sebagian kecil menunjukkan leokosit urin tidak normal. Leukosit urine tidak normal paling banyak ditemukan pada ibu hamil trimester III, Hal ini disebabkan oleh perubahan yang terjadi pada ibu hamil. Peningkatan hormon esterogen dan progesteron pada ibu hamil mengakibatkan terjadinya perubahan organ-organ termasuk organ pada sistem genetourinaria. Tidak menjaga kebersihan genital juga dapat menjadi faktor meningkatnya leukosit didalam urine karena adanya proliferasi mikroorganisme yang dapat menyebabkan infeksi saluran kemih. Ibu hamil dengan kadar leukosit urine tidak normal $(\geq 5 / \mathrm{LPB})$ mempunyai resiko $7,76 \%$ lebih besar mengalami partus prematurus iminens dari pada ibu hamil dengan kadar leukosit dalam urin normal (<5/LPB) (Prawirohardjo $S$, 2011).

Volume kandung kemih akan meningkat seiring perkembangan janin yang semakin membesar. Dalam kondisi ini ibu hamil akan kesulitan mengosongkan kandung kemih sepenuhnya sehingga memungkinkan bakteri tertinggal dan mengakibatkan infeksi. Jumlah leukosit dapat meningkat secara bertahap, diiringi dengan peningkatan usia kehamilan (Dzulfikar HL, 2017). Penelitian serupa juga menyebutkan bahwa sebanyak 9 responden (29\%) ibu hamil trimester III mengalami peningkatan leukosit. Leukosit dapat meningkat akibat stress fisiologis yang diinduksi oleh kehamilan (Santoso APR; Laila M, 2019).

Karakteristik kehamilan keberapa dapat menyebabkan nilai jumlah leukosit yang normal atau tidak normal. Hal ini disebabkan karena ibu hamil pertama kalinya dapat mengalami peningkatan jumlah leukosit dikarenakan perasaan cemas, stress ataupun respon imun yang menurun sedangkan pada wanita yang telah hamil untuk ke 2 dan ke 3 kalinya dapat pula terjadi peningkatan jumlah leukosit yang dapat berpengaruh terhadap infeksi (Maizah, 2018); (Pughikumo OC; Pughikumo DT; Omunakwe HE, 2015). 
Adanya infeksi saluran kemih pada ibu hamil khususnya trimester III sangat erat kaitannya dengan komplikasi kehamilan preeklamsi. Resiko preeklamsi meningkat karena adanya beban inflamasi ibu (Easter SR; Cantonwine \& DA, 2016). Manifestasi klinik ISK yang umum pada kehamilan adalah bakteriuria asimtomatik, sistitis akut, dan infeksi saluran pernafasan akut. Piolonefritis, escherihia coli menjadi organisme yang paling sering diisolasi pada ISK. Semua ibu hamil harus di screening untuk mendiagnosis ISK (Yin LK ; Nalliah S, 2007). Jumlah leukosit dan neutrophil meningkat secara bertahap dan signifikan dari trimester ke-1 hingga ke-3. Peningkatan jumlah monosit menjadi signifikan hanya selama trimester 3 . Jumlah eosinophil tidak berubah secara signifikan selama kehamilan. Jumlah basophil menurun secara signifikan selama trimester ke-2 (Lurie $\mathrm{S}$, Rahamin E, Piper I, Golan A, 2008).

Leucocytosis selama trimester I berhubungan signifikan untuk terjadinya komplikasi obstetric dan persalinan preterm (Tzur T; Weintraub AY; Sergienko R, 2013). Perubahan fisiologis pada kehamilan dan masa nifas dipengaruhi oleh perubahan hormonal. Banyak juga perubahan hematologi juga terjadi selama periode ini, yang harus menjadi perhatian penting ahli hematologi (Candra S; Tripathi AK; Mishra s; Amzarul M; Vaish AK, 2012). Ibu hamil harus di screening untuk mengetahui adanya bakteriurea diawal kehamilan, ibu dengan infeksi saluran kemih harus mendapatkan antimikroba yang aman untuk ibu dan bayinya, setelah selesai pengobatan ibu harus tetap di follow up karena beresiko terjadinya infeksi saluran kemih berulang (Glaser A.P and Schaeffer A.J., 2015)

\section{SIMPULAN}

Ibu hamil trimester III mengalami leukosit urine tidak normal terbanyak yang disebabkan oleh perubahan yang terjadi selama kehamilan, jumlah leukosit yang tidak normal dapat menyebabkan infeksi saluran kemih bahkan beresiko terjadinya persalinan prematur dan gangguan pertumbuhan janin. Ibu hamil perlu memperhatikan asupan gizi dan personal hygine sejak awal kehamilan karena kasus infeksi saluran kemih rentan terjadi pada ibu hamil. Diharapkan pemeriksaan gambaran leukosit pada ibu hamil dapat menjadi standar pemeriksaan penunjang kehamilan yang wajib ada selain pemeriksaan heamoglobin, sebagai upaya preventif mencegah terjadinya infeksi saluran kemih pada ibu hamil.

\section{DAFTAR PUSTAKA}

Alvina, Wiradharma, D., Halim, L., Pusparini, Noor, S., dan Muliadi. (2013). Penuntun Praktikum Patologi Klinik Kedokteran Gigi. CV Sagung Seto.

Arianda D. (2015). Urinalisa, Kimia Klinik seri 1 Sistem Urinaria dan Pemeriksaan. AM Publishing.

Ariffriana, D., Taher, E., dan Wahidah, I. N. (2016). Kimia Klinik. EGC.

Candra S; Tripathi AK; Mishra s; Amzarul M; Vaish AK. (2012). Physiological Changes in Hematological Parameters during Pregnancy. Indian Journal Hematol Blood Transfus, 28(3), 144-146.

https://doi.org/10.1007/s12288012-0175-6

Dzulfikar HL. (2017). Gambaran Leukosit Pada Ibu Hamil di Rumah Sakit Hasanah Graha Afiah Depok Pada April 2016 - 
Juli 2017. Skripsi Program Studi Kedokteran Dan Profesi Dokter Fakultas Kedokteran Dan Ilmu Kesehatan Universitas Islam Negeri Syarif Hidayatullah Jakarta.

Easter SR; Cantonwine, \& DA, ; Zera $\mathrm{CA}$; Lim $\mathrm{KH}$; Parry SI ; McElrath TF. (2016). Urinary tract infection during pregnancy, angiogenic factor profiles, and risk of preeclampsia. American Journal of Obstetrics and Gynecology, 214(3), 387.e1387.e7.

https://doi.org/10.1016/j.ajog.201 5.09.101

Gandasoebrata R. (n.d.). Penuntun Laboratorium Klinik. In 2011. Dian Rakyat.

Glaser A.P and Schaeffer A.J. (2015). Urinary Tract Infection and Bacteriuria in Pregnancy. The Urologic Clinics of North America, 42(4), 547.

Guyton, A. C., Hall, J. E. (2014). Buku Ajar Fisiologi Kedokteran (12th ed.). EGC.

Lurie S, Rahamin E, Piper I, Golan A, S. O. (2008). Total and differential leukocyte counts percentiles in normal pregnancy. European Journal of Obstetrics and Gynecology and Reproductive Biology, 136(1), 16-19. https://doi.org/10.1016/j.ejogrb.20 06.12.013

Maizah. (2018). Gambaran Jumlah Leukosit pada Ibu Hamil Trimester Satu Di Desa Blaban Kecamatan Batumarmar Pamekasan Madura. Karya Tulis Ilmiah. STIKES Insan Cendekia Medika Jombang. Jombang.
Prawirohardjo S. (2011). Ilmu Kebidanan (4th ed.). Yayasan Bina Pustaka Sarwono Prawirohardjo.

Pughikumo OC; Pughikumo DT; Omunakwe HE. (2015). White Blood Cell Counts In Pregnant Women in Port Harcourt, Nigeria. IOSR Journal of Dental and Medical Sciences (IOSR-JDMS), 14(3), 1-3. https://doi.org/10.9790/085314320103

Saimin J, Ashaeryanto, \& Asmarani. (2018). Prevalensi bakteriuria asimtomatik pada ibu hamil. Medula Jurnal Ilmiah Fakultas Kedokteran Universitas Halu Oleo, 6(1), 495-499.

Santoso APR; Laila M. (2019). Hubungan Leukosit Dan Protein Urine Pada Ibu Hamil Trimester III Di Puskesmas Klampis Bangkalan Madura. Medical Technology and Public Health Journal, 3(2), 101-106. https://doi.org/10.33086/mtphj.v3i 2.1206

Tzur T; Weintraub AY; Sergienko R. (2013). Can leukocyte count during the first trimester of pregnancy predict later gestational complications? Archives of Gynecology and Obstetrics, 287(3), 421-427. https://doi.org/10.1007/s00404012-2603-0

Yin LK; Nalliah S. (2007). Urinary Tract Infections In Pregnancy. Malaysian Family Physician, 2(2), 54-57. https://doi.org/10.1097/00003081195803000-00008 
Jurnal Penelitian Perawat Profesional, Volume 3 No 3 Hal 541 - 548, Agustus 2021 Global Health Science Group 